\title{
(WHY) ARE ECONOMISTS DIFFERENT?
}

\author{
GEBHARD KIRCHGAESSNER
}

CESIFO WORKING PAPER No. 1396

CATEgory 2: Public Choice

FEBRUARY 2005

An electronic version of the paper may be downloaded

- from the SSRN website:

www.SSRN.com

- from the CESifo website:

www.CESifo.de 


\title{
(WHY) ARE ECONOMISTS DIFFERENT?
}

\begin{abstract}
After presenting some casual evidence about the difference between economists and the rest of the population, first the survey and experimental evidence which has been presented on this topic during the last 20 years is discussed. But can these results really be transferred to real world situations? To show this, examples of referenda results in Switzerland are presented where the citizens decided against recommendations of most economists. But what is so particular in economic theory that causes these different convictions? Some explanations are given with respect to positive economic theory and with respect to the normative convictions of economists. The paper concludes with possible consequences which economists might draw.
\end{abstract}

JEL Code: B40.

Keywords: cooperative behaviour, indoctrination, self-selection, referenda results, economic model of behaviour, commitment, fairness of the market, economists.

\author{
Gebhard Kirchgaessner \\ University of St. Gallen \\ SIAW-HSG \\ Bodanstr. 8 \\ 9000 St. Gallen \\ Switzerland \\ Gebhard.Kirchgaessner@unisg.ch
}

Revised Version, November 2004. - Presidential Address, delivered at the Annual Meeting of the European Public Choice Society, Berlin, April 17, 2004. I am grateful to LARS P. FELD (University of Marburg) for helpful comments and suggestions. 


\section{Introduction: Some Observations}

"Are economists different, and if so, why?", was the title of a paper by J.R. CARTER and M. IRONS (1991) published in the Journal of Economic Perspectives thirteen years ago. Are they more conservative than the general public as 32 years earlier G. STIGLER (1959) already assumed, who told us "that the professional study of economics makes one politically conservative"? (p. 522.) He defined 'conservative' in the following way: "I shall mean by a conservative in economic matters a person who wishes most economic activity conducted by private enterprise, and who believes that abuses of private power will usually be checked, and incitements to efficiency and progress usually provided, by the force of competition." (p. 524.) Economists are different, and in some sense more conservative; there is a gap in our societies between the economic elite and the other elites, especially the cultural one. Let me first demonstrate this with two pieces of casual evidence.

In 2003, I participated in a public panel discussion in Vienna. The topic was the economic model of behaviour in the age of globalisation. The discussion took place in the nice and rather imperial surrounding of the Vienna city hall. It was obvious from the beginning that the organisers were rather critical of economists. I had the privilege to start the discussion and, applying the "weak rationality principle" following, e.g., G. HOMANS (1961, p. 80) who wrote about the modern conception of homo oeconomicus that "the new economic man is plain man", I tried to convince the floor of the general applicability of the economic model and that this has nothing to do with the process of globalisation; that one should not mix these two issues. After me, a professor of political science from Innsbruck was speaking. She presented - at least as far as I think - rather outdated rigid traditional Marxist theses which were, of course, quite common among left-wing people in the German speaking countries in the years of the 68-movement. This woman accused the capitalists, especially the American ones, and, of course, also the bourgeois economists who are the ones who preach the capitalist ideology, as being responsible for all evils in the world, from the exploitation of workers via the imperial war which the United States fight in the Iraq up to the cutting of subsidies for cultural institutions in Austria like theatres and opera houses. But what really was astonishing was not so much that this woman was presenting such theses; there are always people who are somewhat behind their time, and some of these - sometimes rather intelligent - people are also professors. No, what really was astonishing was that probably more than half of the auditorium was in favour of this woman's views, especially as this auditorium did not at all consist of flippy young people. On the contrary, the majority of people in the room were rather distinguished ones at our age, part of the cultural elite of Vienna. The discussion indicated a deep gap between two elites in our societies, the economic on the one side and the cultural on the other side, and communication between these two elites seems to be rather difficult.

One might think of this occurrence as being just an accident or, perhaps, being only typical for Austria, but certainly not for other countries. According to the results of B.S. FREY et al.

1. For this principle see G. KIRCHGÄSSNER (2004). 
(1984) published twenty years ago, Austrian economists have been to the left of their colleagues of other countries insofar as they were more in favour of Keynesian economic policy and, therefore, of state interventionism as, e.g., their Swiss, German, or American colleagues. Insofar, the whole Austrian society might be politically left of the societies of other countries. But such a suspicion is missing the point. I personally do not believe that the Austrian people are - on average - politically significantly more left-wing than people from other countries. Moreover, it is bad economics to explain differences in behaviour by differences in preferences. But more importantly: There is another somewhat more general observation which corroborates the impression of a gap between these two elites.

Take any good German or Swiss newspaper. You will always find that the cultural part is politically far left from the economic part; the cultural part is more in favour of social democratic parties or - at least - of the left wings of the non-socialist parties which many of those European parties have, while the journalists writing in the economic part are almost always strongly opposed to socialist ideas. If we apply a uni-dimensional scale where the right end denotes a position of being strongly in favour of market mechanisms and being highly sceptical about state interventions, while the left end of the scale denotes just the opposite, you will find that the political part of these newspapers is in the median position (of this newspaper) while the economic part is considerably right and the cultural part considerably left of the political part. This holds for the Frankfurter Allgemeine Zeitung, which is the internationally best known daily German newspaper, in the same way as for the Neue Zürcher Zeitung which has a reputation for being the qualitatively best daily newspaper in German language, as well as for DIE ZEIT, which has a reputation for being the qualitatively best weekly newspaper in German language. While the former two newspapers have a clear position in the right political spectrum, the ZEIT is somewhat left of the median position, but the economic part of the ZEIT might even be right to the cultural part of the Neue Zürcher Zeitung. Though I have only little personal experience, I believe that you can make similar observations in other, that is in non-German speaking European countries as well, as, e.g. Le Monde in France.

This gap between the economic and the cultural elite might be more significant in the European countries than in North America. On the other hand, academic economists are today with respect to their political identifications - on the average - significantly right of the general public. This also holds for the United States, as R.F. HAMILTON and L.L. HARGENS (1993) show. They report the results of a survey taken in 1984. According to those, only 27.7 percent of economics professors identified themselves as being left or liberal, compared to 39.5 percent of all 4'944 professors asked, 66.1 percent of political scientists and even 78.4 percent of sociologists. ${ }^{2)}$ Moreover, B. CAPLAN (2002) has recently shown that there is a big gap between U.S. economists and the general public with respect to economic questions; he accuses

2. This is quite different from the situation in 1969. In that year, 57.1 percent of all economics professors identified themselves as being left or liberal, compared to 54.4 percent of all professors, 69.9 percent of political scientists and 79 percent of sociologists. Thus, economists moved from a position which was left to the median (of all professors) to a new position which is clearly right to the median. The fact, that the size of the sample was 58'313 and, therefore, about twelve times the 1984 sample can hardly account for this dramatic shift. 
the latter of having "systematically biased beliefs about economics". And, especially in the United States - much more than in Europe - Public Choice economists (and political scientists) have the reputation and are accused of being politically biased towards the right. Therefore, in order to understand the own position, this problem might be even more relevant for public choice scholars than just for ordinary economists, and it is, therefore, a topic, public choice scholars should think about.

In the following, I will first discuss the survey and experimental evidence which has been presented on this topic during the last 20 years (Section 2). The open question is, however, whether these results can really be transferred to real world situations. To show this, I present examples of referenda results in Switzerland where the citizens decided against the recommendations not only of most economists but also of most economic parties and interest groups (Section 3). But then, we have to ask what is so particular in economic theory that causes different convictions of economists compared to the rest of the world. I try to explain the difference first with respect to positive economic theory (Section 4) and second with respect to the normative convictions most economists have (Section 5). I conclude with possible consequences economists might draw from all this (Section 6).

\section{Economists are Different (I): Survey and Experimental Evidence}

The literature about differences between economists and the general public started in the eighties with surveys among economists about the working of the price system. The first paper was a questionnaire among American economists done by J.R. KEARL et al. (1979). It was no surprise that in this survey a large majority of economists believed in the functioning of the market system. Studies for Austria, France, the Federal Republic of Germany and Switzerland followed and produced quite similar results. ${ }^{3)}$ It was the conviction of the various authors of these studies that the general public does not have the same strong belief in the working of the market system as the economists. As evidence for this B.S. FREY (1986) pointed to the result that economists working in the government had already less trust in the market system than academic economists; while, for example, 45 percent of the academic economists believed that minimum wages increase unemployment, only 33 percent of the economists working in the government did hold the same belief.

The next step in this line of research was the paper by D. KAHNEMANN, J. KNETSCH and R. THALER (1986). Given an artificial situation of excess demand for snow shovels due to an unexpected snow storm, they asked in a randomly selected survey among residents of two Canadian metropolitan areas, Toronto and Vancouver, how the respondents evaluated the fairness of the price system. The result was that - not surprisingly - a large majority of the respondents were convinced that the use of the price system in such a situation is unfair or even very unfair.

3. See the overview in B.S. FrEY et al. (1994). 
B.S. FreY and W.W. POMmerehne (1993) used first the same and second a quite similar question in Germany (West-Berlin) and Switzerland (Zürich), exchanging the snow shovels after a snow storm with water bottles at a sightseeing point on a mountain on a particularly hot day. For both (artificial) situations they got quite similar results which were also similar to the U.S. results: About 80 percent of the respondents considered the use of the market system in these situations as being unfair or even very unfair. In addition, they extended the design by asking which of the following four allocation procedures would be considered as being fair or unfair: the price system, the traditional allocation of first come first served, a random assignment, or distribution via a public administration. The random procedure was considered as being the most unfair, closely followed by the price mechanism, while the traditional procedure was considered as being fair by 76 percent.

To compare the perceptions of economists with those of the general public, in a further study, B.S. FreY and W.W. POMMEREHNE together with B. GYGI (1993) added a survey among economic students (among them many business economists) at the universities of Zürich and of the Saarland. A huge majority of 64 percent of the economists also considered the price increase as being unfair in such a situation, but this was significantly less than the 84 percent of the general public. Thus, not all economic students had internalised the ethics of the price system, but still considerably more than the general public. In both groups, behind the traditional system of first come first served, the distribution via the public administration got the second place with respect to its fairness, but way behind the traditional system.

A further result of this study is that there are only slight differences between beginning and higher grade economists. This is interesting evidence insofar as one major point of discussion in the literature is whether such results stem from learning or, to state it less politely, from indoctrination, or from self-selection. The indoctrination hypothesis is quite prominent among economists. As already G. STIGLER (1959, p. 528) wrote: "The main reason for the conservatism [of economists] surely lies in the effect of the scientific training the economist receives. He is drilled in the problems of all economic systems and in the methods by which a price system solves theses problems." (p. 528) If the results of B.S. FREY, W.W. POMMEREHNE and B. GYGI (1993) can be generalised, G. STIGLER is mostly wrong: They find only very weak evidence for an indoctrination effect and, therefore, assume that it is mainly self-selection.

This study has, however, been criticised by J. HAUCAP and T. JUST (2004) because the ceteris paribus assumption is not fulfilled: it is neither controlled for (expected future) income nor for demographic factors like gender and age. To overcome these shortcomings at least partially, J. HAUCAP and T. JUST replicated the experiment with their own students at the University of the German Federal Armed Forces in Hamburg. They argue that they "do not have to control for (expected) income, education level, gender, nationality or age, as the students are extremely homogenous in these respects." (p. 2) Due to the special situation in which their students are, this might be true: They only asked male students, and all their students will (if they succeed) stay in the army for at least 12 years and become officers. The 'general public' is represented in their investigation by engineering students and students from the other social sciences. 
The results are quite different from those of B.S. Frey, W.W. Pommerehne and B. Gygi (1993). Only forty percent of the first year economists (including business economists) considered the price system as being fair, whereas there were 60 percent of the advanced economists. Thus, there is a clear and highly significant indoctrination effect, and the share of those economists who consider the price system as being fair is much higher than that at the universities of Zürich and of the Saarland. Moreover, while only 46 percent of the business students consider the price allocation as being fair, it were nearly 70 percent of the economics students. Thus, G. STIGLER (1959) seems to be right.

It is difficult to see what causes the huge differences of the results. It is obvious that the Hamburg students are much less representative for all economic students than those of Zürich and Saarbrücken. Thus, the quantitative results of this study cannot reasonably be transferred to the general (German) students' population. On the other hand, to test just the single hypothesis whether indoctrination plays a role or not it is a huge advantage to have such a homogenous group as in Hamburg; this comes close to the situation of laboratory experiments. Thus, we face the well known problem of external versus internal validity.

There are other survey results which also show differences between economists and noneconomists. R.H. FrANK, TH. GILOVICH and D.T. REGAN (1993) mailed questionnaires to 1245 randomly selected college professors asking them (besides other things) not only whether they participate in presidential elections but also to report the annual dollar amount of different kinds of charitable donations. While there was no real difference in voting behaviour, the share of 'pure' free riders among economists, i.e. those who never gave money to any charity, was 9.3 percent, compared to figures between 1.1 and 4.6 percent in the other disciplines.

The common weakness of all these studies is, however, that they can tell something about the preferences of the different groups but not necessarily about their actual behaviour. Of course, there were no incentives for strategic behaviour when these questions were asked. Thus, the talk-is-cheap argument is not valid here. Nevertheless, it is completely open what these results imply for the actual behaviour of economics and other students.

An alternative research strategy which uses laboratory experiments is not subject to this suspicion. As far as I see, G. MARWELL and R.E. AMES (1981) were probably the first employing this strategy. They showed in a public good experiment that high-school majors, that is noneconomists (including probably some future economists), voluntarily contributed approximately twice as much to the public good than first year graduate students in economics. There was also a huge difference in what the two groups considered as being a fair contribution to the public good. ${ }^{4)}$

Similar results have been derived for the ultimatum game. Economists behave more selfish or, to say it a little bit more polite, more in accordance with traditional game theory. In the study

4. See also the prisoner dilemma experiment reported in R.H. FrANK, TH. GILOVICH and D.T. REgAN (1993) which produced similar results. 
by J.R. CARTER and M.D. IRONS (1991) mentioned above, for example, when 10 U.S. Dollars were at stake the economists accepted on average a minimum of 1.70 U.S. Dollar or proposed to keep 6.15 U.S. Dollars, while non-economists wanted to get at least 2.70 U.S. Dollars and proposed to keep 5.44 U.S. Dollar, on average. Thus, economists behave in such situations not as self-interested as traditional economic theory predicts, but significantly more than noneconomists do. In the last twenty years, quite a lot of different experimental studies have been undertaken which all corroborated this fact. Though these results have been mainly derived from students, it seems reasonable to expect similar differences in behaviour from economists and non-economists after they have finished their studies.

Again, the question which was mainly discussed in this literature was whether this is the result of indoctrination or of (self-)selection: Are those students who start economics already more selfish than the rest of the population, or do they learn this habit during their studies? The problem here is more serious than with respect to the evaluation of the market solution, as the moral dimension is more obvious. If studying economics makes students more selfish as, e.g., R.H. FranK, TH. GiloviCH and D.T. Regan $(1993,1996)$ assume, then those professors who teach economics might be guilty (at least in the eyes of non-economists) of making those students more selfish. As co-operation and even altruistic behaviour is necessary in many situations for the well-functioning of a society, teaching economics might be of ambiguous social value. If, on the other hand, "economists are born, not made", as J.R. CARTER and M.D. IRONS (1991) state, then professors of economics might plea for 'not guilty'; the difference between economists and non-economists might just be given by nature.

There is some further strong evidence which points to the difference between economists and non-economists, at least of the male ones. R. SELTEN and A OCKENFELS (1998) performed a solidarity game. In three-person groups people had the 2/3 chance to win DM 10.00. Before the decision was made, the players were asked how much they would be prepared to give in the case of winning to the one or two possible losers in their group. There was a remarkable difference between economists and non-economists, but only among the male ones: Female economists were prepared to give nearly the same amount as female non-economists. A similar result has been produced by B. FrANK and G.G. SchulzE (2000). They investigated whether economics makes citizens corrupt. Overall, they found that economists are significantly more corrupt than non-economists, while they were unable to find the gender effect known from other experiments. ${ }^{5)}$ But disaggregating the four groups, they found that male economists are the most corrupt ones, while male non-economists are the least corrupt ones, the two female groups being in between, with the female economists being only a little bit more corrupt (which is not statistically significant) than the female non-economists. The statistically significant difference between economists and non-economists does, in this setting, only hold for the male subjects. Given the differences in these studies, it is an open question whether the self-selection of male and female students follows different patterns and/or whether they respond differently to educational influences. Thus, these experiments give no clear support to either of the two hypotheses.

5. For references of the gender effect see R. SELTEN and A. OCKENFELS (1998). 
One major problem with these and other, similar studies is, however, that people play (or talk) and not really act. It is again the problem of external validity. To overcome this, A.M. YETZER, R.S. GOLDFARB and P.J. JOPPEN (1996) performed a 'Lost-Letter' experiment, a technique which is well known in psychology. $\left.{ }^{6}\right)$ They put 10 one U.S. Dollar bills with a corresponding letter in unsealed, stamped white envelopes. They left them in classrooms at the George Washington University shortly before classes begun: 32 in graduate economics classes and 32 in graduate classes of other disciplines, in particular psychology, political science and history. ${ }^{7)}$ The results are striking: 56 percent of the letters left in economics classes were returned, but only 31 percent of those left in non-economics classes. Though this difference is statistically significant only at the 10 percent level, it is definitely not compatible with the hypothesis that economics students are less cooperative than those studying other subjects.

Another problem of all these experiments is that the students do not spend their own money. The behaviour of individuals might be quite different if they have to spend (or keep) their own money compared to a situation where they just decide about 'given money'. To overcome this problem, B.S. FREY and S. MEIER (2003) conducted a field experiment at the University of Zürich. At this university, every semester all students have to decide on contributing to two official social funds in addition to the compulsory tuition fee. One fund offers cheap loans for needy students (Loan Fund) while the other fund supports foreign students (Foreign fund). Compared to the tuition fee of about 700 Swiss Francs the voluntary contributions of 7 or 5 $\mathrm{CHF}$, respectively, are very small, i.e. the students are in a low cost-situation, but it is, nevertheless, their own money, or at least the money of their parents, which the students spend.

The main result of B.S. FREY and S. MEIER is that students of economics, narrowly defined, the political economists, do not give less than the average of all other students. As Figure 1 shows, in the main stage they contribute even a little more while during their Ph.D. studies they contribute a little bit less than the others but not significantly so. (For the first two years, the introductory phase of the studies, there is no differentiation between political and business economists.) Apparently, those economics students who have a higher willingness to spend are less likely to make a Ph.D. The smaller contributions of the economic students (widely defined) is due to the business economists: They contribute significantly less than the other students. Moreover, it can also be seen that the contributions of the economics students are declining in time. Thus, the longer they stay at the university, the less they spend. However, as this holds for all students and not only for economists, it cannot be the effect of economic education. Thus, FREY and MEIER come to the conclusion that "the lower contribution of business economists, compared to other students, is due to self-selection rather than indoctrination." (p. 461) ${ }^{8)}$

6. It has first been employed by S. Milgram, L. MANn and S. Harter (1965). See also R.N. Zelnio and J.P. GAGNON (1977). These experiments are sometimes called 'Envelope Drop'. See, e.g., E.L. GLAESER et al. (2000).

7. For a more detailed description of the experiment see A.M. YeTZER, R.S. GOLDFARB and P.J. JOPPEN (1996, pp. 180f.).

8. See also S. MEIER and B.S. FrEY (2004), though the results are not so unambiguous as the two authors claim. 
Proportion

(in percent)

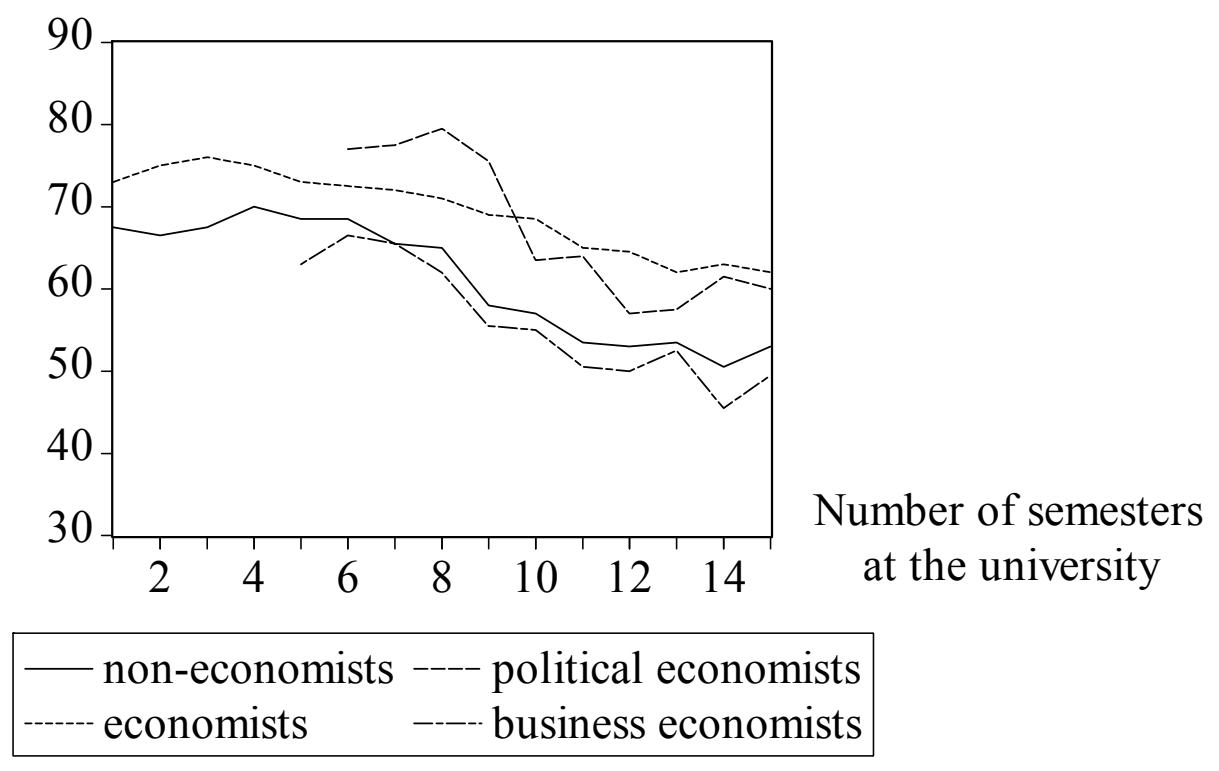

Figure 1: Proportions of Economists and Non-Economists Who Contribute to the Funds ${ }^{9)}$

Though this is obviously the best field study which is available at the moment, it is nevertheless difficult to say whether these results can be generalised. The problem is not so much whether the results from Zürich can be generalised to other cities or countries. This might be the case, as B.S. FreY and S. MEIER (2003) argue. The problem is rather that the students, or at least most of them, are in a low-cost situation. Moreover, what might be even more important is that it is not controlled for their income situation. Moreover, the experimental results from the United States are derived with economics students and not with business students. Thus, it remains an open question why economics students behave more selfish than others in laboratory experiments but not so in the field experiment of Zürich.

A quite different field experiment has been performed by A. BLAIS and R. Young (1999). During the Canadian federal election campaign in 1993, a large number of students were exposed to a ten minute presentation of the rational model of voting behaviour, telling them the well known fact that (under the assumptions of this model) a rational voter should not participate. This reduced - compared to control groups - participation by seven percentage points, mainly because it diminished their sense of duty. ${ }^{10)}$

Thus, the results of the two field studies do not only cover different aspects of behaviour, but they also seem to be in contradiction. But, nevertheless, contrary to what R.H. FRANK, TH. GILOVICH and D.T. REGAN (1996, p. 192) stated, the results of A.M. YETZER, R.S. GoldFARB and P.J. JopPen (1996) as well as B.S. FreY and S. MeIER (2003) have shifted the burden of

9. Source: B.S. FrEY and S. MEIER (2003, p. 452).

10. An earlier study with similar results has been performed by G. BRUNK (1980). 
proof at least somewhat from those who favour the selection hypothesis to those who favour the indoctrination hypothesis. The evidence is conflicting.

However, the reason why we actually can expect conflicting evidence in this area is that - due to the low cost-situations in which they are performed - these laboratory and field experiments tell us more about the preferences of the subjects and less about their actual behaviour in (costly) everyday situations. Economic theory, however, has hardly anything to tell us about the preferences; it is usually about changes in behaviour of individuals as a result of changes in their restrictions. If different people at different places at different points of time have different preferences, we should not be surprised to see different results.

But even if it is only self-selection, the fact remains that at least in some respect and, especially with respect to their perception of economic mechanisms, political economists are different. And at least with respect to this perception it is hardly imaginable that it is not also indoctrination. ${ }^{11)}$ But the much more important question is whether there are real differences in the behaviour of economists compared to other people outside experimental situations. It is, for example, hardly astonishing that people who know formal game theoretic models are more behaving according to the behaviour predicted by these models than those who do not know them. The really interesting question is whether such behaviour really matters in practice, i.e. in real world situations, and, therefore, matters for policy outcomes.

\section{Economists are Different (II): Political Consequences}

At least the different perceptions of the market system matter quite a lot, as can be studied in the Swiss direct democracy. It is not unusual that political decisions are taken in a democracy which do not make sense according to conventional economic wisdom. Public Choice economists usually explain this as the effect of rent-seeking by interest groups; in the theoretical models the interest groups use a bribe to 'buy' the governments decision. However, this is impossible in a direct democracy, because the majority of voters can hardly be bribed. Interest groups may, of course, have an impact on the decisions of the government and/or the parliament. In this respect, the Swiss semi-direct democracy does not differ from the purely parliamentary systems of its surrounding democratic countries. However, if the outcome of the parliamentary process is too far away from the position of the median voter, interest groups and/or parties which lost in the parliamentary process might start a referendum and in this way transfer the decision to the people. ${ }^{12)}$ Then, interest groups can try to influence the voters, but this is much more costly and more difficult than trying to influence the parliamentary process. Moreover, as the empirical evidence shows, it is more difficult to mobilise in favour of a proposal than against it. ${ }^{13)}$ Thus, interest groups have a hard job whenever they

11. For the effects of the education of economists see also T. COUPÉ (2004).

12. See, e.g., L.P. FELD and G. KIRCHGÄSSNER (2001, p. $343 \mathrm{ff}$.$) .$

13. See, for this, H.P. Hertig (1982), C. LONGCHAMP (1991) or G. KIRCHGÄSSNER and T. SchUlZ (2004) with evidence for Switzerland as well as E. GERBER (1999) presenting evidence for the United States. 
want to get additional advantages sanctioned by the voters. Taking the possibility of a referendum into account, the parliamentarians are hesitant to deviate too much from the median voter's position. Correspondingly, only in a minority of cases are signatures collected to get a referendum. But once this is the case, about half of the referenda are successful insofar as the law which has passed the parliamentary process is rejected. It is probably not by chance that in the study of E. KATZ und J. RosenberG (1989) Switzerland is the country with the lowest social losses due to rent-seeking.

Concerning the differences between the general public and the economists with respect to economic policy decisions the really interesting cases are, however, the ones where nearly all economists as well as all or at least most parties and interest groups were in favour of a decision but where the Swiss citizens, nevertheless, rejected it, or when the majority of parties and interest groups were against an initiative but it nevertheless passed. In recent years, this happened several times, especially with respect to liberalisation or privatisation proposals. The most prominent decision was the rejection of the new electricity market law which was rejected on September 22, 2002 by a majority of 52.6 percent. Of course, the crisis in California which happened a few months before this referendum did not help the supporters of the new law, but this law would probably also have been rejected without this event. Apparently, in this respect the Swiss people are more sceptical about the well-functioning of the market mechanism than most economists, and they favour more government regulation or even public production. It is not by chance that Switzerland is today one of the West European countries with the least liberalised electricity market.

Similar decisions took place at the cantonal level when garbage incinerators should be privatised. ${ }^{14)}$ Such privatisations have even been rejected in cases where the Social Democrats did not oppose or even supported it. Moreover, in those 19 cantons where we have cantonal monopolies of insurance for fire and elementary damages, it is impossible to privatise them. In the canton St. Gallen a corresponding initiative was dropped because it did not have any chance of succeeding, and in the canton Zürich the citizens confirmed the cantonal monopoly in 2001 in a referendum with more than 70 percent. $^{15)}$

It is obvious that the Swiss general public or the Swiss median voter, respectively, has a different opinion with respect to these matters than most or even nearly all economists have, and due to the opportunities of direct democracy they have the possibility to override the economic and political elites. Some Swiss economists demand for this reason that, at least at the federal level, direct democracy should be abolished or - at least, be severely restricted - in order to perform a more rational economic policy. ${ }^{16)}$ They are convinced that they are better able to realise their conceptions in a purely representative system. They might even be right; in Continental Europe the European Union which has, as is widely known, a huge democratic

14. This happened, e.g., when the population of the canton Basel-City rejected the privatisation of its garbage incinerator on November 19, 1995, with 58.2 percent. See for this: Basel gegen Privatisierung des Kehrichtwesens, Neue Zürcher Zeitung Nr. 270 vom 20. November 1995, p. 13.

15. See, e.g., G. KIRCHGÄSSNER (2001).

16. See, e.g., S. BORNER and F. BODMER (2004, p. 218f.), or, much more extreme, W. WitTMANN $(1998,2000)$. 
deficit, has enforced privatisation and deregulation in its member countries even against the resistance of their governments. ${ }^{17)}$ Of course, such a paternalistic view is hardly compatible with the basic liberal assumption of citizens sovereignty which underlies the economic model of behaviour.

\section{Why are Economists Different (I)? - Reasons from Positive Theory}

If we accept the results from the laboratories as well as the fields as evidence that economists are really different, the second question which naturally arises is: Why are they different? With respect to self-interested behaviour it might be the case that, as B.S. FREY and S. MAIER (2003) tell us, at least political economists (including public choice scholars) are not different at all or, as J.R. CARTER and M.D. IRONS (1991) (and others) state that this is only due to selfselection. Then, all is a matter of different preferences, and for economists who usually take preferences as given it is obviously not the job to ask why preferences of different people are different. This job is usually assigned to other social scientists, especially sociologists and psychologists.

The situation is, however, quite different with respect to the evaluation of the quality of market solutions. If, as is the case, economists belief more in market solutions than the rest of the population, including other social scientists, then this can hardly be attributed to self-selection but is definitely a problem of learning or indoctrination. But what makes economics different from the other social sciences? Why are economists thinking differently about the solutions of societal problems?

The first answer is, of course, that they apply the economic model to analyse individual behaviour. But this does not really explain the differences, as the general model of Homo oeconomicus is not only also applied in other social sciences as well but also because it is a very general model of explaining individual behaviour; the basic model is the basis of any 'understanding' social science in the Weberian sense. As V. VANBERG (1975) has shown in his dissertation, there is no basic methodological difference between modern economic theory and a sociology in the sense of M. WEBER (1913).

Thus, the problem is not that we assume that individuals have consistent preferences and that, given the information they have about the restrictions, they choose the actions which, at the time the decision is made, they evaluate as being the best one for themselves. The problem is not even the assumption of self-interest which, in a weak form, is compatible with nearly every behaviour, but the additional assumption that individual behaviour is only driven by external incentives, often even reduced to material incentives. Internal incentives as, for example, intrinsic motivation or commitment, do not play a role in this conception. Or, to state it in a Weberian terminology: It is exclusively instrumental rationality, that drives individual

17. A further example of a referendum by which the Swiss people rejected a proposal which was supported by nearly all economists in Switzerland - admittedly with only a very small majority - was the rejection of joining the European Economic Area (EEA) on December 6, 1992. 
actions, and not also value rationality. ${ }^{18)}$ Of course, the market is a system which is nearly totally steered by external incentives, but voting behaviour, for example, is - due to the low cost situation in which voters are - strongly influenced by internal incentives. ${ }^{19)}$ During their education, economists are nearly exclusively trained to take external incentives into account, and even when the economic model of behaviour is applied to non-market situations their focus is on the effects of external incentives. It is hardly astonishing that those who are trained over several years in this thinking are more in favour of market solutions than the rest of the population.

This thinking in incentives has - as everything else - advantages and disadvantages. It recognises problems which are not seen otherwise. The 'paradox of not voting', for example, that a rational voter does not vote, can only be seen as a problem under the assumption that individual behaviour is driven by external motivation. On the other hand, it cannot be solved if we only take instrumental rationality into account. ${ }^{20)}$ If one sees voting as an act of commitment, i.e. if citizens are committed to voting, it is obvious that they will participate even if they see that their single vote does not count. Actually, commitment is the driving force for a wide class of behaviour, behaviour which often cannot reasonably be explained by a strict economic approach. ${ }^{21)}$

This does not imply that the two approaches are incommensurable, as, perhaps, P.K. FEYERABEND (1975) would have said. Commitment (or value rational acting), defined by A.K. SEN (1977, p. 95) "in terms of a person choosing an act that he believes will yield a lower level of personal welfare to him than an alternative that is also available to him" can also be explained within the economic approach. ${ }^{22)}$ In doing so, we have to assume that, first, there are good reasons for the behaviour individuals are committed to, second, that the costs of such behaviour are tolerable, and, third, that the expected result of such behaviour is acceptable. Under these conditions commitment might be a kind of bounded rationality. If, on the other hand, one of these three conditions is violated, especially if the costs become too high, most individuals will change their behaviour. Hardly anybody who explains part of individual behaviour by commitment would deny this. But this is nothing else than to say that sufficiently strong external incentives will change the behaviour of the individuals.

Correspondingly, to take the possibility of commitment into account as, for example, A.K. SEN does, it is not a principle deviation from the economic approach but a change in the perspective. The commitment perspective can be included into the economic one, but starting from the traditional economic perspective one will hardly recognise that there is something like commitment which is relevant for the behaviour of many individuals in many situations.

18. For the distinction between instrumental and value rationality see M. WEBER (1922, pp. 12f.).

19. See for this, e.g., J.M. Buchanan (1954), H. Kliemt (1986) or G. KirCHGÄSSNER (1992).

20. See, e.g., G. KIRCHGÄSSNER and T. SCHUlZ (2004).

21. See also the experimental results in L.P. FELD (2000) and J.-R. TYRAN (2002).

22. Attempts to introduce value rationality in the Weberian sense into the economic model of behaviour have been undertaken, e.g., by S. LINDENBERG (2000) and H. ESSER (2003). 
A second dimension with respect to which we are different is the assumption that preferences are given or, to state it more precisely, that it is hardly possible that public policy can have a systematic impact on the preferences of adult individuals. It is already difficult to systematically influence the preferences of young individuals; otherwise we would have much less problems with them, for example, with their consumption of illegal drugs. Thus, if we want to change the behaviour of individuals, we try to change their restrictions in order to make socially unwanted behaviour desirable from an individual perspective. And even then, we are usually sceptical about the chances for success of such measures, because we acknowledge that people are intelligent and learn and might behave quite differently from what we expect. This renders economists reserved with respect to economic policy matters or politically conservative in the way G. STIGLER (1959) defined it.

Other social scientists question the assumption of given preferences and, therefore, are more ready to assume that preferences can be influenced. Because people do not always behave self-interestedly but also follow moral rules, they give moral suasion much more credit than economists usually do.

A third dimension with respect to which we are different is the problem of emergency, or, the fact that "the whole is more than the sum of its parts". Other social scientists, especially those who are developing system theories, are speaking of properties of economic (and other) systems and the relations between such properties. Economists or, more generally, those social scientists who develop theories based on methodological individualism, speak of unintended side effects of individual actions. Again, these two perspectives are not necessarily contradictive: The systems theory of N. LUHMAN, e.g., can be transformed into a theory based on methodological individualism, as well as the approach of E. DURKHEIM, as R. KÖNIG (1961) has shown. ${ }^{23)}$ The difference is again one of a different perspective.

These two differences have important implications for the way we are thinking of problems of the society in general and of political processes in particular, and, therefore, also about the merits of the market mechanism. People who are looking at the government as being committed to perform a certain policy have a different perspective than those seeing the people working in the government only as seeking their own private interests. The former perspective is not necessarily to the advantage of the government, as voters might punish the government (and next time elect the opposition) due to developments the government is not really responsible for. Take the current situation. As the OECD has told us quite often, the social security systems of all OECD countries will get into troubles and have to be reformed. There are some reforms in several countries, be it Germany, France, or Austria, to name just three. Two of them have a right-wing, one has a left-wing government. The policies they perform are quite similar, and they hardly have a chance for something very different. Nevertheless, as the recent regional elections in all three countries as well as opinion polls show, all three governments are punished for performing such a policy, despite the fact that the oppositions hardly have better conceptions. 
Moreover, those who are taking on the economic perspective will always take into account the unintended consequences of intended actions, especially government actions, and therefore, more or less concentrate on government failure. Those coming from a systems perspective will rather concentrate on market failures. Again, it is a difference in the perspective, not necessarily a basic difference, but it can lead to totally different evaluations of the market system and, therefore, policy conclusions. Taking both perceptions into account, one might become somewhat more hesitant than the average economists to praise the market mechanism and only come to a, as A.K. SEN (1985, p. 19) formulated, "faint praise [of the market mechanism] - not any less, not much more".

\section{Why are Economists Different (II)? - Normative Conceptions}

It is, however, not only a question of positive social theory, but also a question of normative conceptions. Today, at least in our Western societies, nearly everybody underwrites the principle that all individuals should have equal chances in a society. People who are convinced of the allocative efficiency of the market mechanism will usually argue that this principle is put into effect in a market system. Insofar, the market system has a moral quality: It treats all people equally, independent of their sex, age, race or religion, it offers all citizens the same chances, and it offers in most dimensions more chances than any other social co-ordination mechanism. Correspondingly, the concept of 'Ordnungsethik' as developed by K. HomANN regards the design of the economic order (Rahmenordnung) as the only question which is of real ethical relevance in a market society. ${ }^{24)}$ However, most non-economists see the equality principle being violated in a market system, because the individual chances depend on the incomes of the individuals. 'Fair' solutions are for most people solutions in which the outcome is independent of the income of the people affected (but influenced by other criteria like the individual needs, whatever these might be). ${ }^{25)}$ The reason why the market system is considered as being unfair by many non-economists is simply that individuals with higher incomes have better chances in such a system. In such a perception, the traditional first come first served solution is fairer than the market solution because the final allocation is independent of the income positions of the individuals affected; it is in accordance with the egalitarian principle that all people should have the same chances in such situations. The underlying problem is, of course, how 'equality of chances' is defined: While economists usually see the market as a system which guarantees this equality because whoever is willing to pay the price of a good can get whatever he/she wants, other people see exactly this principle as being violated in the market system because the ability to pay depends on the very unequal income positions of the individuals. From this perspective, the market does not guarantee the equality of chances at all. It is against of this background that the RAWLs'ian (1971) difference principle has to be seen: The market system which transforms inequalities of income in inequalities of chances and - by this way - in unequal possibilities to live a good life in a way the individuals want, might nevertheless be seen as being fair as long as it improves the situation of

24. See, e.g., K. Homann and Ch. KirChNER (1995).

25. See the literature about the fairness of the market cited above. 
those who are in the worst position and, therefore, provides them with more chances in this respect.

There is also another but related perspective with respect to which the market system might be seen as being unfair. Let us assume in a utilitarian framework a society with two individuals with identical (and, therefore, comparable) utility functions but different income positions. Assume, that there is just one unit of a special good available, and this good is auctioned. The individual with the higher willingness to pay, that is the rich individual, will get the good, but nevertheless, at least as long as the goods are substitutes in the classical sense, the additional utility of the poor individual would be larger if he could get it than the additional utility of the rich individual. This argument is very often brought forward by ordinary people who accuse the unfairness of the market. Confronted with this argument, (since VILfREDO PARETO $(1896))^{26)}$ economists usually (and correctly) point to the fact that from a scientific point of view individual utilities cannot be compared. However, most other people reject this argument. There are two reasons for this: First, every day we all make utility comparisons. Second, this argument contradicts conceptions of fairness which are quite common and which are more or less, to use an analogue to a phrase of K. POPPER (1972), the core of the "normative commonsense theory' of the large majority of our population. ${ }^{27)}$ The real problem, however, is not that economists reject interpersonal utility comparisons, but that they make such comparisons using (at least implicitly) the KALDOR-HICKS compensation criterion. To argue that a political measure which fulfils the KALDOR-HICKS criterion improves social welfare in a situation when the compensation is not paid demands, however, still more restrictive assumptions than the standard utilitarian framework. And how often are such compensations paid? Nearly never!

This is a basic but nevertheless obvious inconsistency in the argumentation of many if not most economists, and their discourse partners from other social sciences as well as the general public recognise this. It was the German philosopher and economist HANS ALBERT (1953) who, already fifty years ago, pointed to the "failure of the doctrine of the maximisation of goods" as he called it, that is the failure to confuse the maximisation of the willingness to pay with the maximisation of social welfare. This inconsistency largely impairs the credibility of economists in public discussions (as well as in discussions with other social scientists).

\section{Concluding Remarks}

I started with the observation that there is a gap between the economic elite and the rest of our society. This gap might be wider in Continental European compared to Anglo-Saxon countries, but the experimental and survey evidence (which first came from the United States) indicates that it exists there as well. This gap divides us also from most of our colleagues in other social sciences.

26. Actually, the first version of this principle goes back to F.Y. EDGEWORTH (1881). See for this A.P. KIRMAN (1987).

27. K.R. POPPER (1972, pp. 32) speaks of the "Commonsense Theory of Knowledge". 
I have tried to show that there are reasons for this gap which lie in the economic methodology as well as in the normative common sense most economists share. These reasons are definitely not bad reasons. And if we have good reasons and see economics as a social science, the discussion about indoctrination versus self-selection is not very interesting. This holds not only because it is extremely implausible that there is not at least some indoctrination, or, to say it somewhat more friendly, learning in this respect. It should be obvious that the study of economics changes the perception individuals have of the market mechanism; we who are teaching economics would miss our job if this would not be the case. Insofar, a corroboration of the indoctrination hypothesis should not be considered as a blame for us. Ask anyone of the natural sciences and he will confirm that his studies have changed his perception of the natural world as well. Why should this be different for social scientists with respect to the social world, and for economists with respect to economic mechanisms? On the other hand, if we see that economists outside the universities are more sceptical in this respect, that is that the impact of our teaching is weakening in time, we see that our impact is limited. But this is again a corroboration of the indoctrination hypothesis, only in the other direction.

We should insist that there are good reasons for being different, at least with respect to our scientific methodology, but we should also not deny that other groups might also have good reasons for using their perspectives. Thinking in incentives, taking preferences as given and considering unintended consequences of individual actions are important heuristics to understand social processes, but we should also acknowledge that external incentives are not sufficient to explain quite a lot of socially important behaviour and that altruism, intrinsic motivation, commitment as well as reciprocity also play an important role in human behaviour. Moreover, to make real progress in science which goes beyond a Kuhnian normal science, we need an open society with a plurality of approaches and competing perspectives, especially in the social sciences, and not a closed scientific community.

Thus, we have to choose: Either we restrict the application of our model to the analysis of market processes, where external incentives really play a very dominant role, or we accept that other incentives also play a role; and then we are also able to analyse, for example, political processes. For a political economist the choice should be obvious. But even the limitation to market processes is not without problems: As E. FEHR has shown, fairness and reciprocity considerations play an important role in traditional markets as well. ${ }^{28)}$

Moreover, we should be a little more careful with our value judgements, distinguish them from scientific statements, and acknowledge that others might also have good reasons for their value judgements, even if they are different from ours.

Finally, respecting the additional motivations and the other perspectives should help us to bridge the gap between us and the rest of our societies, especially also our sister social sciences, as the new development between economics and psychology in recent years shows. We will remain to stay different, perhaps somewhat more conservative than the others in our po- 
litical convictions, but we should be able to better communicate with others. This is especially important if we belief, as, I think, we all do, that economic theorising can help to cope with the economic and social problems our societies face today.

\section{Zusammenfassung}

Nachdem an Fallbeispielen Unterschiede in den Auffassungen von Ökonomen einerseits und dem Rest der Bevölkerung andererseits aufgezeigt wurde, wird zunächst die empirische Evidenz zu diesem Faktum aus Umfragen und Experimenten zusammengefasst. Wie weit sind diese Ergebnisse auf Situationen realen Handelns übertragbar? Um dies zu zeigen, wird auf Ergebnisse von Referenden verwiesen, in welchen sich die Bürger entgegen den Empfehlungen fast aller Ökonomen entschieden haben. Dann wird gezeigt, welche Eigenheiten der (positiven) ökonomischen Theorie wie der normativen Überzeugungen der (meisten) Ökonomen zu diesen Unterschieden führen. Die Arbeit schliesst mit Hinweisen zu Konsequenzen, zu denen sich Ökonomen in dieser Situation veranlasst sehen könnten.

\section{References}

H. AlBeRT (1953), Der Trugschluss in der Lehre vom Güter-Maximum, Zeitschrift für Nationalökonomie 14 (1953/54), pp. 90 - 103.

S. BORNER and F. BODMER (2004), Wohlstand ohne Wachstum: Eine Schweizer Illusion, Orell Füssli, Zürich 2004.

A. BLAIS and R. Young (1999), Why Do People Vote? An Experiment in Rationality, Public Choice 99 (1999), pp $39-55$.

G. BRUNK (1980), The Impact of Rational Participation on Voting Attitudes, Public Choice 35 (1980), pp. $549-564$.

J.M. BUCHANAN (1954), Individual Choice in Voting and in the Market, Journal of Political Economy 62 (1954), pp. $334-343$.

B. CAPLAN (2002), Systematically Biased Beliefs about Economics: Robust Evidence of Judgemental Anomalies from the Survey of Americans and Economists on the Economy, Economic Journal 112 (2002), pp. $433-458$.

J.R. CARTER and M. IRONS (1991), Are Economists Different, and If So, Why?, Journal of Economic Perspectives 5/2 (1991), pp. 171 - 177.

T. COUPÉ (2004), What Do We Know About Ourselves? On the Economics of Economics, Kyklos 57 (2004), pp. $197-216$.

E. DURKHEIM (1895), Les règles de la méthode sociologique, Presses Universitaires de France, Paris 1895; quoted from the English translation: The Rules of Sociological Method, The Free Press, Glencoe (Ill.) 1938.

F.Y. Edgeworth (1887), Mathematical Psychics, Kegan Paul, London 1887.

H. ESSER (2003), Die Rationalität der Werte: Die Typen des Handelns und das Modell der soziologischen Erklärung, in: G. AlBERT et al. (eds.), Das Weber-Payradigma: Studien zur Weiterentwicklung von Max Webers Forschungsprogramm, Mohr Siebeck, Tübingen 2003, pp. 153 - 187. 
L.P. FELD and G. KIRCHGÄSSNER (2001), The Political Economy of Direct Legislation: The Role of Direct Democracy in Local and Regional Decision-Making, Economic Policy 33 (2001), pp. 329 367.

L.P. FELD (2000) and J.-R. TYRAN (2002), Tax Evasion and Voting: An Experimental Analysis, Kyklos 55 (2002), pp. $197-222$.

E. FEHR and S. GÄCHTER (1998), Reciprocity and Economics: The Economic Implications of Homo Reciprocans, European Economic Review 42 (1998), S. 845 - 859.

E. FEHR and S. GÄCHTER (2000), Fairness and Retaliation: The Economics of Reciprocity, Journal of Economic Perspectives 14/3 (2000), pp. 159 - 181.

E. FEHR and K.M. SCHMIDT (1999), A Theory of Fairness, Competition, and Cooperation, Quarterly Journal of Economics 114 (1999), S. 817 - 868.

P.K. FeYERABEND (1975), Against Method, New Left Book, New York 1975; 3rd revised edition: Verso, London and new York 1993.

B. FrAnK and G. Schulze (2000), Does Economics Make Citizens Corrupt?, Journal of Economic Behaviour and Organisation 43 (2000), pp. $101-113$.

R.H. Frank, Th. GILOVICH and D.T. REgAN (1993), Does Studying Economics Inhibit Cooperation? Journal of Economic Perspectives 7/2 (1993), pp. 159 - 171.

R.H. FranK, TH. Gilovich and D.T. Regan (1996), Do Economists Make Bad Citizens?, Journal of Economic Perspectives 10/1 (1996), pp. 187 - 192.

B.S. FrEY (1986), Economists Favour the Price System: Who Else Does?, Kyklos 39 (1986), pp. 537 563.

B.S. FreY and S. MEIER (2003), Are Political Economists Selfish and Indoctrinated? Evidence from a Natural Experiment, Economic Inquiry 41 (2003), pp. 448 - 462.

B. S. FreY and W.W. Pommerehne (1993), On the Fairness of Pricing: An Empirical Survey Among the General Population, Journal of Economic Behaviour and Organisation 20 (1993), pp. 295 307.

B. S. Frey, W.W. Pommerehne and B. Gygi (1993), Economics Indoctrination or Selection? Some Empirical Results, Journal of Economic Education 24 (1993), pp. 271 - 281.

B.S. Frey, W.W. Pommerehne, F. SChNeIDER and G. Gilbert (1984), Consensus and Dissension Among Economists: An Empirical Inquiry, American Economic Review 74 (1984), pp. 986 - 994.

E. Gerber (1999), The Populist Paradox: Interest Group Influence and the Promise of Direct Legislation, Princeton University Press, Princeton 1999.

E. Glaeser, D. LAibson, J.A. Scheinkman and Ch.L. Soutter (2000), Measuring Trust, Quarterly Journal of Economics 115 (2000), pp. $811-846$.

R.F. HAMilton and L.L. HARGENS (1993), The Politics of the Professors: Self-Identifications, 1969 1984, Social Forces 71 (1993), pp. $603-627$.

J. HAUCAP and T. JUST (2004), Not Guilty? Another Look at the Nature and Nurture of Economic Students, Paper presented at the Annual Meeting of the Public Choice Society, Berlin, April 15 18, 2004.

H.P. HeRTIG (1982), Sind Abstimmungen käuflich?, Schweizerisches Jahrbuch für Politische Wissenschaft 22 (1982), pp. $35-58$.

K. HomanN and CH. KiRCHNER (1995), Ordnungsethik, Jahrbuch für Neue Politische Ökonomie 14 (1995), pp. $189-211$.

G.C. Homans (1961), Social Behavior: Its Elementary Forms, Harcourt, Brace and World, New York 1961. 
D. Kahnemann, J. Knetsch and R. Thaler (1986), Fairness as a Constraint on Profit Seeking: Entitlements in the Market, American Economic Review 76 (1986), pp. 728 - 741.

E. Katz and J. Rosenberg (1989), Rent-Seeking for Budgetary Allocation: Preliminary Results for 20 Countries, Public Choice 60 (1989), pp. $133-144$.

J.R. Kearl, C.L. Pope, G.C. Whitung and L.T. Wimmer (1979), A Confusion of Economists?, American Economic Review 69.2 (Papers and Proceedings ) (1979), pp. 28 - 37.

G. KIRCHGÄSSNER (1992), Towards a Theory of Low-Cost Decisions, European Journal of Political Economy 8 (1992), pp. $305-320$.

G. KIRCHGÄSSNER (1999), Homo oeconomicus, Das ökonomische Modell individuellen Verhaltens und seine Anwendung in den Wirtschafts- und Sozialwissenschaften, J.B.C. Mohr (Paul Siebeck), Tübingen, $2^{\text {nd }}$ edition 2000 .

G. KIRCHGÄSSNER (2001), Die Effizienz eines öffentlichen Versicherungsmonopols: Das Beispiel der schweizerischen Gebäudeversicherungen, Zeitschrift für öffentliche und gemeinwirtschaftliche Unternehmen 24 (2001), pp. 249 - 266.

G. KIRCHGÄSSNER (2004), The Weak Rationality Principle, Universität St. Gallen, Volkswirtschaftliche Abteilung, Diskussionspapier Nr. 2004-13, Dezember 2004.

G. KIRCHGÄSSNER and T. SCHUlZ (2004), Expected Closeness or Mobilisation: Why Do Voters Go to the Polls?, Empirical Results for Switzerland, 1981 - 1999, Paper presented at the Meeting of the American Public Choice Society, Baltimore, March 12, 2004.

A.P. KIRMAN (1987), Pareto as an Economists, in: The New Palgrave: A Dictionary of Economics, Vol. 3, Macmillan, London and Basingstoke 1987, pp. $804-809$.

H. KLIEMT (1986), The Veil of Insignificance, European Journal of Political Economy 2 (1986), pp. $333-344$.

R. KÖNIG (1961), Einleitung (Introduction to the German translation):, E. DURKHEIM (1895), Die Regeln der soziologischen Methode, Luchterhand, Neuwied 1961, pp. $19-82$.

S. Lindenberg, (2000), The extension of rationality: Framing versus cognitive rationality, in: J. BAECHLER, F. ChAzel, and R. KAMRANE (eds.), L'Acteur et ses Raisons. Mélanges en l'honneur de Raymond Boudon, Presses Universitaires de France, Paris 2000, pp.168 - 204.

C. LONGCHAMP (1991), Herausgeforderte demokratische Öffentlichkeit: Zu den Möglichkeiten und Grenzen des politischen Marketings bei Abstimmungen und Wahlen in der Schweiz, Schweizerisches Jahrbuch für Politische Wissenschaft 31 (1991), pp. 303 - 326.

N. LuHMANN (1970), Wirtschaft als soziales System, in: N. LuHMANN, Soziologische Aufklärung, Aufsätze zur Theorie sozialer Systeme, Vol. 1, Westdeutscher Verlag, Köln/Opladen 1970, pp. 204 - 231; English translation: The Economy as a Social System, in: N. LuHMANN, The Differentiation of Society, Columbia University Press, New York 1982, pp. 190 - 225.

N. LuHMANN (1988), Die Wirtschaft der Gesellschaft, Suhrkamp, Frankfurt 1988.

G. MARVELL and R.E. AMES (1981), Economists Free Ride, Does Anyone Else?, Experiments on the Provision of Public Goods, IV, Journal of Public Economics 15 (1981), pp. 295 - 310.

S. MEIER and B.S. FreY (2004), Do Business Students Make Good Citizens?, International Journal of the Economics of Business 11 (2004), pp. $141-163$.

S. Milgram, L. MANN and S. HARTER (1965), The Lost-Letter Technique: A Tool of Social Research, Public Opinion Quarterly 29 (1965), pp. 437f.

V. PAReto (1896/7), Cours d'économie politique, Libraire de l'Université, 2 volumes, Lausanne $1886 / 87$.

K.R. POPPER (1972), Objective Knowledge, Clarendon Press, Oxford. 
J. RaWls (1971), A Theory of Justice, Harvard University Press, Cambridge (Mass.) 1971.

R. SELTEN and A. OCKENFELs (1998), An Experimental Solidarity Game, Journal of Economic Behaviour and Organisation 34 (1198), pp. 517 - 539.

A.K. SEN (1977), Rational Fools: A Critique of the Behavioural Foundations of Economic Theory, Philosophy and Public Affairs 6 (1976/77), pp. 317 - 344.

A.K. Sen (1985), The Moral Standing of the Market, in: A.K. SEN, Ethics and Economics, Basil Blackwell, Oxford 1985, pp. $1-19$.

G. STIGLER (1959), The Politics of Political Economists, Quarterly Journal of Economics 73 (1959), pp. $522-532$.

V. VANBERG (1975), Die zwei Soziologien, Mohr (Siebeck), Tübingen 1975.

M. WeBER (1913), Über einige Kategorien der verstehenden Soziologie, reprinted in: M. WeBER, Gesammelte Aufsätze zur Wissenschaftslehre, Mohr (Siebeck), Tübingen, 7. edition 1988, pp. 427 $-474$.

M. WeBER (1922), Wirtschaft und Gesellschaft, Mohr (Siebeck), Tübingen 1922; English translation: Economics and Society: An Outline of Interpretative Sociology, Badminster Press, New York 1968.

M.D. White (2004), Can Homo Economicus Follow Kant's Categorical Imperative?, Journal of Socio-Economics 33 (2004), pp. 89 - 106.

W. WitTMAnN (1998), Die Schweiz: Ende eines Mythos, Wirtschaftsverlag Langen Müller/Herbig, München 1998.

W. WitTmann (2001), Direkte Demokratie: Bremsklotz der Revitalisierung, Huber, Frauenfeld 2001.

A.M. YeTZER, R.S. GoldFARB and P.J. PopPEN (1996), Does Economics Discourage Cooperation? Watch What We Do, Not What We Say or How We Play, Journal of Economic Perspectives 10/1 (1996), pp. $177-186$.

R.N. ZELNIO and J.P. GAGNON (1977), The Viability of the Lost Letter Technique, Journal of Psychology 95 (1977), pp. 51 - 53. 


\title{
CESifo Working Paper Series
}

\author{
(for full list see www.cesifo.de)
}

1333 Martin Peitz and Patrick Waelbroeck, An Economist's Guide to Digital Music, November 2004

1335 Lutz Hendricks, Why Does Educational Attainment Differ Across U.S. States?, November 2004

1336 Jay Pil Choi, Antitrust Analysis of Tying Arrangements, November 2004

1337 Rafael Lalive, Jan C. van Ours and Josef Zweimueller, How Changes in Financial Incentives Affect the Duration of Unemployment, November 2004

1338 Robert Woods, Fiscal Stabilisation and EMU, November 2004

1339 Rainald Borck and Matthias Wrede, Political Economy of Commuting Subsidies, November 2004

1340 Marcel Gérard, Combining Dutch Presumptive Capital Income Tax and US Qualified Intermediaries to Set Forth a New System of International Savings Taxation, November 2004

1341 Bruno S. Frey, Simon Luechinger and Alois Stutzer, Calculating Tragedy: Assessing the Costs of Terrorism, November 2004

1342 Johannes Becker and Clemens Fuest, A Backward Looking Measure of the Effective Marginal Tax Burden on Investment, November 2004

1343 Heikki Kauppi, Erkki Koskela and Rune Stenbacka, Equilibrium Unemployment and Capital Intensity Under Product and Labor Market Imperfections, November 2004

1344 Helge Berger and Till Müller, How Should Large and Small Countries Be Represented in a Currency Union?, November 2004

1345 Bruno Jullien, Two-Sided Markets and Electronic Intermediaries, November 2004

1346 Wolfgang Eggert and Martin Kolmar, Contests with Size Effects, December 2004

1347 Stefan Napel and Mika Widgrén, The Inter-Institutional Distribution of Power in EU Codecision, December 2004

1348 Yin-Wong Cheung and Ulf G. Erlandsson, Exchange Rates and Markov Switching Dynamics, December 2004

1349 Hartmut Egger and Peter Egger, Outsourcing and Trade in a Spatial World, December 2004 
1350 Paul Belleflamme and Pierre M. Picard, Piracy and Competition, December 2004

1351 Jon Strand, Public-Good Valuation and Intrafamily Allocation, December 2004

1352 Michael Berlemann, Marcus Dittrich and Gunther Markwardt, The Value of NonBinding Announcements in Public Goods Experiments: Some Theory and Experimental Evidence, December 2004

1353 Camille Cornand and Frank Heinemann, Optimal Degree of Public Information Dissemination, December 2004

1354 Matteo Governatori and Sylvester Eijffinger, Fiscal and Monetary Interaction: The Role of Asymmetries of the Stability and Growth Pact in EMU, December 2004

1355 Fred Ramb and Alfons J. Weichenrieder, Taxes and the Financial Structure of German Inward FDI, December 2004

1356 José Luis Moraga-González and Jean-Marie Viaene, Dumping in Developing and Transition Economies, December 2004

1357 Peter Friedrich, Anita Kaltschütz and Chang Woon Nam, Significance and Determination of Fees for Municipal Finance, December 2004

1358 M. Hashem Pesaran and Paolo Zaffaroni, Model Averaging and Value-at-Risk Based Evaluation of Large Multi Asset Volatility Models for Risk Management, December 2004

1359 Fwu-Ranq Chang, Optimal Growth and Impatience: A Phase Diagram Analysis, December 2004

1360 Elise S. Brezis and François Crouzet, The Role of Higher Education Institutions: Recruitment of Elites and Economic Growth, December 2004

1361 B. Gabriela Mundaca and Jon Strand, A Risk Allocation Approach to Optimal Exchange Rate Policy, December 2004

1362 Christa Hainz, Quality of Institutions, Credit Markets and Bankruptcy, December 2004

1363 Jerome L. Stein, Optimal Debt and Equilibrium Exchange Rates in a Stochastic Environment: an Overview, December 2004

1364 Frank Heinemann, Rosemarie Nagel and Peter Ockenfels, Measuring Strategic Uncertainty in Coordination Games, December 2004

1365 José Luis Moraga-González and Jean-Marie Viaene, Anti-Dumping, Intra-Industry Trade and Quality Reversals, December 2004

1366 Harry Grubert, Tax Credits, Source Rules, Trade and Electronic Commerce: Behavioral Margins and the Design of International Tax Systems, December 2004 
1367 Hans-Werner Sinn, EU Enlargement, Migration and the New Constitution, December 2004

1368 Josef Falkinger, Noncooperative Support of Public Norm Enforcement in Large Societies, December 2004

1369 Panu Poutvaara, Public Education in an Integrated Europe: Studying to Migrate and Teaching to Stay?, December 2004

1370 András Simonovits, Designing Benefit Rules for Flexible Retirement with or without Redistribution, December 2004

1371 Antonis Adam, Macroeconomic Effects of Social Security Privatization in a Small Unionized Economy, December 2004

1372 Andrew Hughes Hallett, Post-Thatcher Fiscal Strategies in the U.K.: An Interpretation, December 2004

1373 Hendrik Hakenes and Martin Peitz, Umbrella Branding and the Provision of Quality, December 2004

1374 Sascha O. Becker, Karolina Ekholm, Robert Jäckle and Marc-Andreas Mündler, Location Choice and Employment Decisions: A Comparison of German and Swedish Multinationals, January 2005

1375 Christian Gollier, The Consumption-Based Determinants of the Term Structure of Discount Rates, January 2005

1376 Giovanni Di Bartolomeo, Jacob Engwerda, Joseph Plasmans, Bas van Aarle and Tomasz Michalak, Macroeconomic Stabilization Policies in the EMU: Spillovers, Asymmetries, and Institutions, January 2005

1377 Luis H. R. Alvarez and Erkki Koskela, Progressive Taxation and Irreversible Investment under Uncertainty, January 2005

1378 Theodore C. Bergstrom and John L. Hartman, Demographics and the Political Sustainability of Pay-as-you-go Social Security, January 2005

1379 Bruno S. Frey and Margit Osterloh, Yes, Managers Should Be Paid Like Bureaucrats, January 2005

1380 Oliver Hülsewig, Eric Mayer and Timo Wollmershäuser, Bank Loan Supply and Monetary Policy Transmission in Germany: An Assessment Based on Matching Impulse Responses, January 2005

1381 Alessandro Balestrino and Umberto Galmarini, On the Redistributive Properties of Presumptive Taxation, January 2005

1382 Christian Gollier, Optimal Illusions and Decisions under Risk, January 2005 
1383 Daniel Mejía and Marc St-Pierre, Unequal Opportunities and Human Capital Formation, January 2005

1384 Luis H. R. Alvarez and Erkki Koskela, Optimal Harvesting under Resource Stock and Price Uncertainty, January 2005

1385 Ruslan Lukach, Peter M. Kort and Joseph Plasmans, Optimal R\&D Investment Strategies with Quantity Competition under the Threat of Superior Entry, January 2005

1386 Alfred Greiner, Uwe Koeller and Willi Semmler, Testing Sustainability of German Fiscal Policy. Evidence for the Period 1960 - 2003, January 2005

1387 Gebhard Kirchgässner and Tobias Schulz, Expected Closeness or Mobilisation: Why Do Voters Go to the Polls? Empirical Results for Switzerland, 1981 - 1999, January 2005

1388 Emanuele Bacchiocchi and Alessandro Missale, Managing Debt Stability, January 2005

1389 Assar Lindbeck and Dirk Niepelt, Improving the SGP: Taxes and Delegation rather than Fines, January 2005

1390 James J. Heckman and Dimitriy V. Masterov, Skill Policies for Scotland, January 2005

1391 Emma Galli \& Fabio Padovano, Sustainability and Determinants of Italian Public Deficits before and after Maastricht, January 2005

1392 Angel de la Fuente and Juan Francisco Jimeno, The Private and Fiscal Returns to Schooling and the Effect of Public Policies on Private Incentives to Invest in Education: A General Framework and Some Results for the EU, January 2005

1393 Juan C. Conesa and Carlos Garriga, Optimal Response to a Demographic Shock, January 2005

1394 Christian Gollier, Optimal Portfolio Management for Individual Pension Plans, February 2005

1395 Ruslan Lukach, Joseph Plasmans and Peter M. Kort, Innovation Strategies in a Competitive Dynamic Setting, February 2005

1396 Gebhard Kirchgässner, (Why) Are Economists Different?, February 2005 